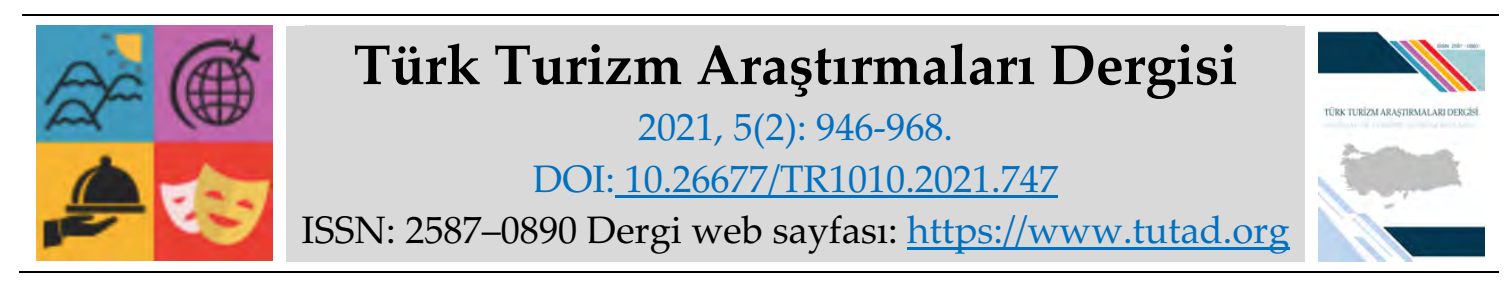

ARASTTIRMA MAKALESI

\title{
Yenice Mutfak Kültürünün Vegan Mutfak Kapsamında İncelenmesi
}

Prof. Dr. Nuray TÜRKER, Karabük Üniversitesi, Safranbolu Turizm Fakültesi, Karabük, e-posta: nturker@karabuk.edu.tr

ORCID: https://orcid.org/0000-0001-5701-5674

Öğr. Gör. Sibel AYYILDIZ, Karabük Üniversitesi, Eflani Meslek Yüksekokulu, Karabük, e-posta: sibelayildiz@karabuk.edu.tr

ORCID: https://orcid.org/0000-0003-0701-2445

$\ddot{O} z$

Bu çalışma Karabük iline bağlı Yenice ilçesinin sahip olduğu yöresel mutfak kültürünün “Vegan Mutfak" kapsamında incelenmesini amaçlamaktadır. Nitel araştırma yönteminin benimsendiği bu araştırmada Yenice'de yaşayan yöre mutfağına hakim 7 kadın ile görüşme yapılmış, elde edilen veriler betimsel analiz yöntemi kullanılarak analiz edilmiştir. Çalışma, Yenice'de tüketilen yemeklerin vegan yiyecekler olduğunu göstermektedir. Yörede yaşayan insanların beslenmesinde ağırlıklı olarak Isırganotu, Ebegümeci, Tatala, Ispıt otu (Kabalak) gibi otlar ile kara lahana (mancar) gibi sebzeler ve kara bakla, mısır gibi karbonhidrat içeren aynı zamanda bitkisel protein açısından zengin yiyecekler kullanılmaktadır. Çalışma kapsamında ayrıca, yemekler araştırmaya katılanlar tarafından yapılmış, yazarlar tarafından standart reçeteleri oluşturulmuş ve fotoğraflanmış, böylece yöresel yemekler kayıt altına alınmıştır. Çalışma, somut olmayan kültürel mirasın korunması ve yöresel yemeklerin sürdürülebilirliğine katkı sağlanması bakımından önem taşımaktadır.

Anahtar Kelimeler: Vejeteryan, Vegan, Yerel Mutfak Kültürü, Yenice.

Makale Gönderme Tarihi: 04.01.2021

Makale Kabul Tarihi: 03.06.2021

\section{Önerilen Atıf:}

Türker, N. ve Ayyıldız, S. (2021). Yenice Mutfak Kültürünün Vegan Mutfak Kapsamında İncelenmesi, Türk Turizm Araştırmaları Dergisi, 5(2): 946-968.

(c) 2021 Türk Turizm Araştırmaları Dergisi. 


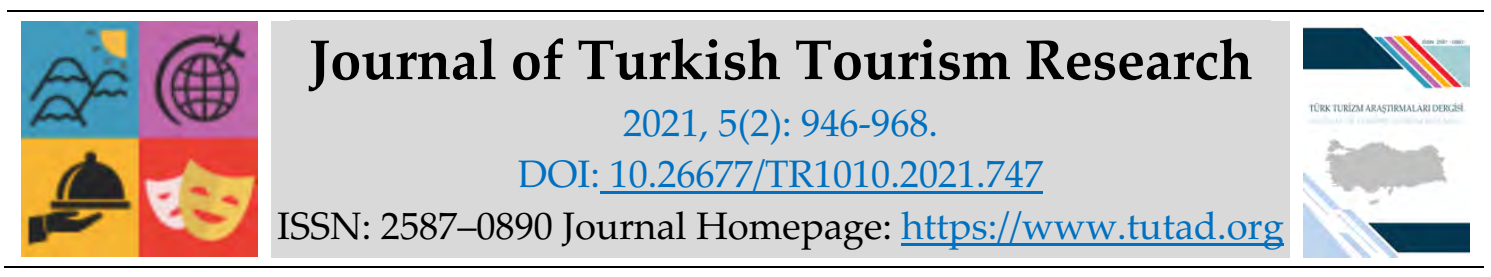

\title{
RESEARCH PAPER
}

\section{Examination of Yenice Cuisine in the Scope of Vegan Cuisine}

Prof. Dr. Nuray TÜRKER, Karabük University, Safranbolu Faculty of Tourism, Karabük, e-mail: nturker@karabuk.edu.tr

ORCID: https://orcid.org/0000-0001-5701-5674

Lecturer Sibel AYYILDIZ, Karabük University, Eflani Vocational School, Karabük, e-mail: sibelayildiz@karabuk.edu.tr

ORCID: https://orcid.org/0000-0003-0701-2445

\begin{abstract}
This study aims to examine the local cuisine of Yenice district of Karabük province within the scope of "Vegan cuisine". In this study, in which the qualitative research method was adopted, 7 women who lived in Yenice and had full knowledge of the local cuisine were interviewed and the data were analyzed using the descriptive analysis method. The study shows that the meals consumed in Yenice are vegan foods. In the diet of the people living in the region, herbs such as Nettle, Mallow, Tatala, Borage (Kabalak), vegetables such as black cabbage (mancar) and foods rich in carbohydrates such as broad beans and corn are also used. Within the scope of the study, the meals were cooked by the participants, standard recipes were prepared and photographed by the authors, thus local dishes were recorded. The study is important in terms of preserving the intangible cultural heritage and contribution to the sustainability of local cuisine.
\end{abstract}

Keywords: Vegeterian, Vegan, Local Cuisine, Yenice.

Received: 04.01.2021

Accepted: 03.06.2021

\section{Suggested Citation:}

Türker, N. and Ayyıldız, S. (2021). Examination of Yenice Cuisine in the Scope of Vegan Cuisine, Journal of Turkish Tourism Research, 5(2): 946-968.

(c) 2021 Türk Turizm Araştırmaları Dergisi. 


\section{Gíriş}

Bir toplumun beslenme biçimini ve kültürünü yansıtan yemek pişirme sanatının geçmişi eski çağlara kadar uzanmaktadır (Freedman, 2008: 7). Tarihi çağlar boyunca gıda yalnızca karın doyurmak için kullanılan bir meta değil aynı zamanda sosyal dönüşümün, toplumsal örgütlenmenin, jeopolitik rekabetlerin, savaşların ve iktisadi ilerlemelerin bir katalizörü olmuştur (Standage, 2016: 11).

Yemek seçimleri bir taraftan sınıf, ırk, toplumsal cinsiyet rolü ve yaş gibi birçok kritere göre belirlenirken, diğer taraftan kimin neyi, ne zaman yiyebileceği yazılmamış olan kurallarla baskın kültür tarafından belirlenmiştir. Bazı yiyecekler geleneksel olarak bazı dinlere, bazı milletlere ve bazı cinsiyetlere ait olmuştur (Sezgin ve Ayyıldız, 2019: 507). Örneğin Hıristiyan Batı dünyasında et, eskiden şehveti teşvik eden bir yiyecek olarak görüldügünden manastırlarda yasaklanan veya sınırlanan bir gidadır. Fakat sebzelere yönelik bir övgü de yapılmamıştır. Hatta sebzeler asillerin tüketmediği, çoğunlukla köylülerin tüketmesinin uygun görüldüğü yiyecekler olmuştur (Freedman, 2008: 12). Çeşitli etlerin tüketimi (tavşan, at, domuz, bazı deniz mahsulleri vb.) dinlere göre hatta aynı din içerisinde farklı mezheplere göre bile farklılık göstermektedir (Tez, 2015: 15).

Bir toplumun beslenme biçimi kültürel olduğu kadar coğrafi unsurlar tarafından da belirlenmiştir. Bir toplumda neyin tüketildiği gastro-coğrafya bir başka ifade ile yaşanılan yörede yetişen gıda ürünleri ile yakından ilişkilidir.

Bode (2000), iklim, toprak, mevsimler, insanların yeme-içme alışkanlıkları, tarım ve teknolojinin gelişmişlik düzeyi gibi faktörleri dikkate alarak kuzey, orta ve güney kuşağı olmak üzere dünyanın üç gastro-coğrafi kuşağa ayrıldığını belirtmektedir. Hububat, kökler, balık, av etleri ve sığırın ağırlıkta olduğu kuzey kuşağında, temel besinler ekmek, sebzeler, balık ve etten oluşur. Orta kuşak ise pirinç, şarap ve peynir kuşağı olarak ifade edilir. Avrupa sömürgeleri olması ve emperyalizm kaynaklı olarak kültürün değişikliğe uğraması nedeniyle özelliklerini net bir şekilde ortaya koymak zor olsa da güney kuşağının yeme içme alışkanlıkları genel olarak sebze üzerine kuruludur. Bazı bölümlerinde ise balık ve et odaklı beslenmeye rastlanır.

Benzer şekilde bir ülkede farklı coğrafyalarda yetişen ürünlerin o yörelerde yaşayan yerel halkın beslenmesini belirlediği söylenebilir. Örneğin; Ege Bölgesi coğrafyanın elverişliliği nedeni ile çok sayıda doğal otun yetiştiği bir bölgedir. Bu da yemek menülerinde ot yemeklerinin ve mezelerinin ağırlığının hissedilmesine neden olmaktadır.

20. yüzyılın ortalarından itibaren değişen ekonomik, teknolojik, sosyal ve kültürel şartlar, yemek konusunda insanların yararlanabileceği birçok alternatif beslenme biçiminin ortaya çıkmasını sağlamıştır (Sezgin ve Ayyıldız, 2019: 507). Bu beslenme alternatiflerinden en dikkat çekici olanları; Vejetaryen ve Vegan beslenme biçimleridir. Vejetaryenliğin bir türü olan veganlığa odaklanan bu çalışma iki temel bölümden oluşmaktadır. Çalışmanın ilk bölümünde Vejeteryanlık ve Veganlık olguları incelenmiş ve tanımlanmış, ikinci bölümde ise vegan yemekler üzerine Yenice'de yapılan alan araştırmasından elde edilen bulgular sunulmuştur. Bu kapsamda Yenice'nin ağırlıklı olarak bitkisel kaynaklardan ve otlardan oluşan yemek kültürü incelenmiş ve şehirde yapılan yemekler kültürel bağlamı da dikkate alınarak; içine konan malzemeler, malzemelerin özellikleri, tarifleri ve fotoğrafları ile sunulmuştur.

\section{VEJETERYANLIK ve VEGANLIK KAVRAMLARI}

En yaygın tanımıyla "vejetaryenlik" hayvansal kaynaklı gidalar yerine bitkisel kaynaklı gıdaların tüketimini içeren bir beslenme şeklidir. "Vejetaryen" ise bitkisel gıda ağırlıklı olarak beslenen, 
hayvansal gıdaları (kırmızı et, tavuk, balık, yumurta, süt ve süt ürünleri) sınırlı miktarda tüketen kişiler olarak tanımlanmaktadır (Özcan ve Baysal, 2016:102; Kınıkoğlu, 2016: 17; Ilgaz vd., 2016:45; Şanlıer ve Ertaş 2018: 133).

Vejetaryenler, ete karşı tiksinme duymaları, hayvanlara zulmedilmesi ya da hayvanların öldürülmesi nedeniyle et tüketimine karşı olumsuz bir tutuma sahiptirler (Petti vd., 2017: 230). Araştırmalar bu kişilerin vejetaryen olma nedenleri arasında; ekolojik duyarlılık, lezzet, kültürel veya dini inançlar, etik değerler ve biyoetik yaklaşımlar (hayvanların öldürülmesine karşı duyulan tepki ve hayvanlara saygı, hayvan refahı) ve sağlık gibi faktörlerin olduğunu ortaya koymaktadır (Wrenn, 2011: 22; Ruby, 2012: 144; Tunçay, 2016:52, Mariotti, 2017: 314, Petti vd., 2017: 229, Özmen, 2017:1).

Vejetaryenler tüketilen hayvansal ürünün türüne göre farklı isimlerle adlandırılmaktadır. Sadece kırmızı et tüketmeyen kişilerin bazıları yumurta yemeyip, süt ve süt ürünlerini tüketmekte ya da yumurta yiyip süt ve süt ürünlerini tüketmemektedir (Tunçay-Son, 2016:7). Bu bağlamda vejetaryen çeşitleri aşağıda sunulmaktadır.

Tablo 1. Vejetaryen Çeşitleri

\begin{tabular}{|c|l|c|l|}
\hline $\begin{array}{c}\text { Vejetaryen } \\
\text { Çeşitleri }\end{array}$ & $\begin{array}{c}\text { Tüketilebilen } \\
\text { Hayvansal Gıda }\end{array}$ & Vejetaryen Çeşitleri & \multicolumn{1}{|c|}{$\begin{array}{c}\text { Tüketilebilen } \\
\text { Hayvansal Gıda }\end{array}$} \\
\hline $\begin{array}{c}\text { Lakto-ovo } \\
\text { Vejetaryen }\end{array}$ & $\begin{array}{l}\text { Yumurta, süt ve süt } \\
\text { ürünleri }\end{array}$ & Vegan & $\begin{array}{l}\text { Hiçbir hayvansal ürün } \\
\text { tüketilmez }\end{array}$ \\
\hline $\begin{array}{c}\text { Lakto } \\
\text { vejetaryen } \\
\text { Ovo- } \\
\text { vejetaryen }\end{array}$ & Süt ve süt ürünleri & Polo-vejetaryen & $\begin{array}{l}\text { Kümes hayvanları } \\
\text { Tavuk, su ürünleri, süt } \\
\text { ve süt ürünleri ile } \\
\text { yumurta }\end{array}$ \\
\hline $\begin{array}{c}\text { Semi- } \\
\text { vejetaryen }\end{array}$ & $\begin{array}{l}\text { Kümes hayvanları, } \\
\text { su ürünleri, süt ve } \\
\text { süt ürünleri ile } \\
\text { yumurta }\end{array}$ & Esnesco-vejetaryen Veganlık & $\begin{array}{l}\text { Vegan olmanın nedeni } \\
\text { etik ve ekolojiktir }\end{array}$ \\
\hline Rawist & $\begin{array}{l}\text { Hiçbir hayvansal } \\
\text { ürün tüketilmez. }\end{array}$ & Fruitarians / Fruit-fed & $\begin{array}{l}\text { Sadece meyve ve } \\
\text { sebzelerle beslenirler. }\end{array}$ \\
\hline Freegan & $\begin{array}{l}\text { Mutlak bir } \\
\text { vejetaryen değildir. } \\
\text { Fakat hayvan } \\
\text { temelli ürünler } \\
\text { yemez. }\end{array}$ & \multicolumn{2}{|l}{} \\
\hline
\end{tabular}

Kaynak: Karabudak, 2012: 8; Özcan ve Baysal, 2016: 102; Tunçay-Son, 2016:8; Hossain, 2016: 533; Altaş, 2017:405; Marioitti ve Dagnieli, 2017: 4.

Tablo 1'de verilen vejeteryan beslenme kategorilerinin dişında bu kategorilerde yer almayan vejetaryenlik çeşitleri de bulunmaktadır. Bunlar; Strictly vegetarian (katı vejetaryen), True vegetarian (gerçek vejetaryen), Low-meat eaters (az et tüketenler), Occasional meat eaters (ara sıra et yiyenler) olarak siralanabilir (Marioitti, 2017:5).

Veganlık, et, balık, kümes hayvanı, yumurta, bal, hayvansal süt ve türevlerinin tüketilmediği, yaşamın bitkisel kaynaklı gıda ürünleri ile sürdürüldüğü ve hayvanlardan üretilen tüm ticari ürünlerin kullanılmaktan kaçınıldığı beslenme ve yaşam biçimidir (Ilgaz vd., 2016:45). Başka bir 
ifade ile veganlar sadece gida ürünlerini değil aynı zamanda hayvanlar üzerinde test edilen ürünleri (kozmetik ürünler, deterjan, diş macunu vb.) kullanmaktan kaçınırlar. Hayvanlar sömürü amaçlı kullanıldığından veganlar sirklere gitmezler, ayrıca canlı hayvanların kullanıldığı filmleri de izlemezler (Çetin, 2014: 2, Yegen ve Aydın, 2018: 96). Bireylerin vegan yaşam tarzını benimsemesinin çok çeşitli motivasyonları bulunabilir. Bu motivasyonlar bazı bireylerde dini inançlar veya kişisel tercihler iken (Sünnetçioğlu vd., 2017: 242), bazı bireylerde ete karşı tiksinme veya hayvanlara karşı yapılan zulmü önleme isteği gibi durumlar olabilmektedir (Petti vd., 2017: 230). Bu beslenme şeklini benimsemiş olan veganlar hayvansal olmayan, tamamen bitkisel gida içeren çikolata, kek ve pasta gibi gıda ürünlerini de tüketmektedir (Çetin, 2014: 2).

İnsanlık tarihi ile ilgili bilgiler; eski dönemlerde insanların beslenmelerinin ağırlıklı olarak bitki temelli olduğunu göstermektedir. Ancak, vejetaryenlik olgusunun tarihsel geçmişi kesin olarak bilinmemektedir. Felsefe ve matematiğe katkıları ile tanınan Pisagor (Pythagoras) etsiz, doğal ve sağlıklı bir diyeti teşvik etmiş, Platon, Sokrates ve Horace gibi filozoflar da bu öneriyi desteklemişlerdir. 6. yüzyılda Rönesans döneminde Leonardo da Vinci'nin vejetaryen beslenmeyi uyguladığı bilinmektedir. Aydınlanma çağında vejetaryen beslenme tarzını uygulayanlar arasında Tyron, Rousseau, Voltaire ve Wesley de bulunmaktadır (Leitzmann, 2014:497). İlk kez 1944 yılında İngiliz Sanatçı Donalt Watson tarafından kullanılan "Vegan" sözcüğü (Kınıkoğlu, 2016: 15), 20. yüzyılın son on yılında bitkisel beslenme odaklı bilimsel araştırma konuları arasına girmiştir (Leitzmann, 2014: 500).

Veganlık kavramı toplumsal cinsiyet açısından incelendiğinde kadınların erkeklere oranla daha az et tükettikleri görülmektedir (Şahin, 2017: 95). Ilgaz vd., (2018) göre; ete ve etteki proteine erkeğin kadından daha fazla ihtiyacı olduğu ile ilgili değerlendirmeler bulunmaktadır. Adam (2019)'a göre, toplumda hangi yiyeceklerin hangi cinsiyetlere daha uygun olduğunu ortaya koyan yargılar vardır. "Adam olmak" deyimi kimlik açısından "gerçek" erkeklerin yapıp yapmadığ1 şeyler ile ilişkilendirilir, örneğin; gerçek erkekler kiş (sebzeden yapılan bir çeşit yemek) yemez. Keza bitki de kadınlara atfedilen bir terminoloji olarak kullanılmaktadır. Kadınlar narin ve uysal oldukları için bitki yemekleri ile, aktif oldukları düşünülen erkekler ise hayvan eti ile ilişkilendirilmiştir. Batı Avrupa, Afrika ve Asya kültürlerinde et, erkeklik, iktidar ve bekaret konusu ile ilişkilendirildiğinden ataerkilliğin simgesi olmuştur (Ruby ve Heine, 2011: 448). İngiltere' de 1991 yılında yapılan bir araştırmada kadın katılımcıların erkeklere kıyasla vejeteryan olma oranının daha yüksek olduğu ortaya çıkmıştır (Dewan, 2017: 19). Başka bir araştırmaya göre ise 18-34 yaşlarındaki kadınların diğer yaş grubundaki kadınlara kıyasla vejetaryen olma olasılıklarının daha yüksek olduğu belirlenmiştir (Ginsberg, 2017: 4).

Hububatlar, baklagiller, kök bitkiler, yağlı tohumlar, meyve, sebze, fındık ve mantar, soya proteini gibi bitki kökenli gıda maddelerinin tüketilmesi ile vejetaryen ve vegan beslenmenin sağlık açısından olumlu katkıları arasında bir ilişki olduğuna inanılmaktadır (McEvoy vd., 2011: 2288; Yegen ve Aydın, 2018: 96). Bu beslenme tarzını benimseyen insanların çoğu daha sağlıklı olduklarına inanmaktadır. Bu düşüncenin de etkisiyle vejetaryenlik/veganlık son on yılda giderek daha popüler hale gelmiştir (Sünnetçioğlu vd., 2017: 242).

Vejetaryenler ve veganlar ile ilgili yapılan çalışmalarda; vejetaryen beslenme tarzını benimseyen bireylerin sağlığa uygun bir şekilde beslenmeleri halinde vejetaryen olmayanlara göre daha düşük kan basıncı düzeylerine, daha düşük vücut ağırlığına (düşük beden kitle indeksi) ve düşük homosistein düzeyine sahip oldukları tespit edilmiştir. Bunun yanı sıra; vejetaryenler ile yapılan çeşitli kohort (belli bir ortak özelliği olan kişiler) araştırmalarda ise; vegan beslenmenin metabolik hastalık kaynaklı ölüm oranını azalttığı ortaya çıkmıştır (Çetin, 2014: 10). Bazı çalışmalar, vejetaryen beslenmenin özellikle kolon kanserine karşı koruyucu etkilerinin olduğunu ortaya koymaktadır (Şanlıer ve Ertaş, 2018: 137). 
Vejeteryanlığın ve veganlığın sağlıklı seçenekler olduğu şeklindeki popüler inanışa rağmen, vegan diyetin dengeli olmasını sağlamak için bazı önlemlerin alınması gerekir (Petti vd., 2017:230). Bu kısıtlayıcı diyet modelinde beslenme için gerekli olan maddelerin eksik alındığı ile ilgili endişeler bulunmaktadır. Mevcut bilgiler, sağlık açısından olumlu sonuçlarının yanında vejetaryenliğin olumsuz sonuçlarının da olduğu ortaya koymaktadır. Örneğin; hayvansal ürünlerin vücuda alınmaması, su ve yağda çözünen vitaminler ile mineraller gibi bazı elementlerin yetersiz alımına yol açabilmektedir (McEvoy, Temple ve Woodside, 2012: 2288). Yapılan bir çalışmada vejetaryen yemeklerin, vejetaryen olmayanlara göre oldukça düşük protein kalitesine sahip olduğu, hatta bazı vejetaryen yemeklerinin hiç protein içermediği tespit edilmiştir. Ayrıca, hayvansal kaynaklı gıdalarda bulunan kalsiyum, demir, çinko, D vitamini ve B12 vitamininin vejetaryen yemeklerde yetersiz olduğu belirlenmiştir (Şanlıer ve Ertaş, 2018:137).

\section{YENİCE MUTFAK KÜLTÜRÜ}

Batı Karadeniz bölümünde bulunan Karabük ilinin bir ilçesi olan Yenice 1150 km²lik bir yüzölçüme sahiptir. Karadeniz kıyı şeridinden $60 \mathrm{~km}$. içeride yer alan Yenice orman dokusu bakımından oldukça zengindir. Halk, temel geçim kaynaklarını hayvancılık, orman işçiliği ve madencilikten sağlamaktadır. Yükseltisi 2000 metreye varan dağlık ve tepelik alanları ve engebeli arazi yapısı ilçede tarımsal faaliyetleri kısıtlamaktadır. Yenice, yazları serin, kışları soğuk ve yağışlıdır. Nemli, yağışlı ve sisli bir iklime sahip olan ilçede, yıllık ortalama sıcaklık 13,6.C, yıllık ortalama yağış miktarı 693,3 mm'dir aksine Yenice Irmağı vadisinde iklim mikro klima özelliği gösterir (Yenice Kaymakamlığı, 2020a). İklimsel özellikler, Yenice'de çok zengin bir bitki çeşitliliğinin yetişmesine neden olmaktadır. Bu bağlamda, bölgede yetişen otlar, mantarlar ve baklagiller Yenice'de dikkate değer bir vegan mutfağının gelişmesine zemin hazırlamıştır.

Yenice mutfağının sebze, ot ve mantarlardan oluşan karakteristik yapısı, bulunduğu coğrafi konum ile ilişkilidir (Canbulat, 2008: 8). Yenice'de Mancar (karalahana) ve ıspıt otu öne çıkar. Bu otların yanı sıra; 1sırgan, pazı, semizotu, ebegümeci, hindiba, dil buran, kazayak, gelincik, çoban ekmeği, kara kavruk, madımak, teke sakalı, yemlik, toklamaç, labada otları yemek yapımında kullanılan diğer otlardır. Yabani mantar açısından da zengin olan yörede, ilkbahar ve sonbaharda doğada yetişen ve yöresel olarak köşk, cincile, göbelek, içi kızıl, kanlıca, karakulak, kayışkan, meşe, mıh tepesi, sarıgül, tellice, kara göçen, kabak, koç, saçak, bağrı kışlı, cücüle, çivi başı, geyik, halı saçağı, karaağaç, ayı mantarı olarak adlandırılan pek çok mantar türü de vegan yemeklerin temel malzemelerini oluşturur. Bu vegan malzemeler çeşitli tahıllar ile birlikte pişirilerek hem tatları zenginleştirilir hem de besleyici değerleri arttırılır (Canbulat, 2013; Karabük Valiliği, 2015: 217; Karabük İl Kültür ve Turizm Müdürlügü̈, 2019).

Proteinin çoğunlukla baklagillerden sağlandığı Yenice mutfağının geleneksel yemekleri; karalahana, malay, şaptak, mısır çorbası, ceviz helvası, bazlama, katlaç, lokma, ve muska gibi yemek, hamur işleri ve tatlılardan oluşur (Karakırık ve Cebecik, 1996: 52). Yenice'de dügün yemeği olarak misafirlere keşkek çorbası, mısır çorbası, göce çorbası, et, pilav, nohut yemeği, fasulye yemeği, barbunya yemeği, kara mancar dolması (bulgurlu) ile komposto, baklava ve kesme kadayıf tatlıları ikram edilir (Karabük Valiliği, 2015: 216). Yenice'de önemli günlerde; düğün ve bayramlarda yapılan tatlı Muska (Hamaliğbağı) tatlısıdır. Ayrıca, Karabük ilinde yalnızca Yenice yöresinde bayramlar için yaptırılan "Ceviz Helvası" günümüze kadar gelmiş önemli bir tatlıdır (Yenice Kaymakamlığı, 2020b).

Yenice'de yazın kışın kullanılmak üzere bazı gıda hazırlıkları yapılmaktadır. Kışlık gıdalar arasında kuru kıyma, kavurma, kemikli et kavurması, sucuk gibi hayvansal ürünler bulunmaktadır. Yufka, yayım, tarhana, pekmez, salça, sirke, keşkek, hoşaf olarak tüketilen pestil, çeşitli meyve kuruları (elma, armut, ayva, dut vb.), şerbet olarak tüketilen çeşitli meyve ezmeleri 
(kızılcık, ayva, erik, vişne, kuşburnu vb.), yemeklik olarak kullanılan çeşitli sebze kuruları (dilme fasulye, kurutulmuş patlıcan, dolma biber, sivri biber, bamya vb.), çeşitli sebzelerden yapılan turşular (biber, domates, lahana, salatalık, vb.), meyvelerden yapılan çeşitli reçeller (kızılcık, çilek, vişne, ayva, üzüm vb.) diğer kışlık hazırlıklar arasındadır (Karabük Valiliği, 2015: 217; Karabük İl Kültür ve Turizm Müdürlüğü, 2019).

\section{YÖNTEM}

Yenice ilçesinin mutfak kültürü tipik vejetaryen beslenme biçimini yansıtmaktadır. Araştırmanın amac1, Yenice bölgesinin sahip olduğu yöresel mutfak kültürünün "Vegan Mutfağı" kapsamında incelenmesi ve vegan yemeklerin belirlenmesidir. Araştırmada ayrıca Yenice yemeklerinin kültürel arka planının (yemek pişirmede kullanılan araç-gereçler, en çok tüketilen besinler, yağlar, baharatlar vb.) ortaya çıarılması amaçlanmıştır. Böylece, somut olmayan kültürel miraslarımızdan biri olan gastronomi ve yemek kültürünün kayıt altına alınması, yok olmasının engellenmesi ve sürdürülebilirliğine katkı sağlanması da amaçlanmaktadır. Bu bağlamda çalışma ile ilgili kaynak taraması yapılmış ancak, Yenice mutfağına ilişkin yalnızca bir kaynağa ulaşılabilmiştir. Alanyazında Yenice mutfağı ve yemek kültürü ile ilgili çok sınırlı sayıda çalışmanın olması bu araştırmanın yapılmasında önemli bir etken olmuştur.

Nitel araştırma deseninin benimsendiği araştırmada Yenice'de yaşayan yedi kadın katılımcı ile açık uçlu sorulardan oluşan yarı yapısal bir görüşme formu kullanılarak yüz yüze görüşme yapılmıştır. Nitel araştırmalar, gözlem, görüşme ve doküman analizi gibi nitel veri toplama tekniklerinin kullanıldığı, algıların ve olayların doğal ortamda gerçekçi ve bütüncül bir biçimde ortaya konmasına yönelik nitel bir sürecin izlendiği araştırma olarak tanımlanabilir (Yıldırım ve Şimşek, 2016: 41). Nitel araştırmanın en önemli özelliği, araştırmacının katılımcıları gözlemleyerek, mülakatlar ve odak grup görüşmeleri gibi araçlarla doğrudan açık uçlu sorular sorarak veya anketleri kullanarak veriler toplamasıdır (Creswell, 2017: 4). Odak grup görüşmeleri nitel veri toplamada önemli bir işleve sahiptir. Sorulan sorulara verilen yantlar, gruptaki bireylerin birbirleriyle etkileşimleri sonucu oluşur. Bu tür görüşmelerde grup dinamikleri sorulara verilen yanıtların kapsamını ve derinliğini etkilemektedir (Yıldırım ve Şimşek, 2016: 157).

Tablo 2. Araştırmada Belirlenen Tema ve Kodlar

\begin{tabular}{|c|l|}
\hline Temalar & Kodlar \\
$\begin{array}{c}\text { Yemek Yapımında } \\
\text { Kullanılan Ekipman } \\
\text { ve Gı́da Malzemeleri }\end{array}$ & $\begin{array}{l}\text { Mutfak ekipmanları), } \\
\text { (2) Yörede en çok tüketilen besin grupları (Eskiden en çok tüketilen besin } \\
\text { grupları), } \\
\text { (3) Yörede en çok tüketilen baharat türleri (Eskiden en çok tüketilen baharat } \\
\text { türleri), } \\
\text { (4) Yörede en çok tüketilen yağ türü (Eskiden en çok tüketilen yağ türü). }\end{array}$ \\
\hline $\begin{array}{c}\text { Yörede Pişirilen } \\
\text { Yemekler }\end{array}$ & $\begin{array}{l}\text { (1) Yöreye özgü sebze ve meyve yemekleri (Eskiden en çok pişirilen sebze } \\
\text { (2) Yöreye özgü ot yemekleri (Eskiden en çok pişirilen ot yemekleri), } \\
\text { (3) Yöreye özgü tahıll ve kurubaklagil yemekleri (Eskiden en çok pişirilen tahıll } \\
\text { ve kurubaklagil yemekleri), } \\
\text { (4) Yöreye özgü vegan tatlı çeşitleri (Eskiden en çok yapılan vegan tatlı). }\end{array}$ \\
& (5) Yenice yöresine ait Ritüel Yemekleri \\
\hline
\end{tabular}


Araştırma, Yenice mutfağına hakim, yemek yapma konusunda deneyimli, yöredeki düğün veya diğer önemli günlerde aşçı olarak tutulan yedi kadın katılımcı ile toplamda 3,5 saat süren odak gurup görüşmesi şeklinde gerçekleştirilmiştir. Böylece, Yenice yöresine ait vegan yemekler saptanmıştır. Araştırma kapsamında yörenin yemek ve tatıları katılımcılar tarafından yapmıştır. Yemeklerin pişirilmesinde kullanılan malzemeler ve ölçüleri standardize edilerek her bir yemeğin standart reçetesi oluşturulmuş ve araştırmacılar tarafından fotoğraflanmıştır.

Katılımcılarla yapılan görüşmelerde sorulan soruların temaları (ana başlıkları) ve kodları Tablo 2'de verilmektedir.

Araştırma 2 ana tema (ana başlık) ve 9 kod çerçevesinde betimsel olarak analiz edilmiş, elde edilen sonuçlar aşağıda sunulmuştur.

\section{BULGULAR}

Araştırmadan elde edilen bulgular, katılımcıların demografik özellikleri, Yemek Yapımında Kullanılan Ekipman ve Gıda Malzemeleri ile Yörede Pişirilen Yemekler ana başlıkları altında verilmiştir. Tablo 3, katılımcıların demografik özelliklerini göstermektedir.

Tablo 3. Araştırmaya Katılanların Profili

\begin{tabular}{|l|l|c|c|c|}
\hline Kod & Ad-Soyad & Yaş & Doğum Yeri & Eğitim Durumu \\
\hline K1 & Hanife Mısırlı & 69 & Devrek $^{*}$ & Okur-Yazar \\
\hline K2 & Durkadın İncebacak & 64 & Yenice $^{*}$ & Okur-Yazar \\
\hline K3 & Azize Karadöngel & 66 & Devrek $^{*}$ & Okur-Yazar \\
\hline K4 & Dudu Mısırlı & 60 & Yenice & Okur-Yazar \\
\hline K5 & Meryem Mısırlı & 50 & Yenice & Okur-Yazar \\
\hline K6 & Hatice Kahveci & 50 & Yenice $^{*}$ & Okur-Yazar \\
\hline K7 & Hatice Sarıvazaz & 76 & Devrek $^{*}$ & Okur-Yazar değil \\
\hline
\end{tabular}

*1936-1953 yılları arasında Yenice Devrek'e bağlı bir nahiyedir.

Katılımcıların ağırlıklı olarak 60 yaşın üzerinde oldukları ve bir kişi hariç tümünün okur-yazar olduğu görülmektedir.

Kullanılan Ekipman ve Gıda Malzemeleri: İlk tema, yörede kullanılan ekipman ve gıda malzemelerini belirlemeyi amaçlamaktadır. Tema dört koddan oluşmakta olup elde edilen bulgular aşağıda maddeler halinde açıklanmaktadır.

(1) Mutfaklarda Kullanılan Pişirme Ekipmanları: Yenice yöresinde eskiden yemek pişirmek için genellikle bakır ve alüminyum tencereler kullanılmaktaydı. Hatta yemek sunumu yapılan bazı tabak ve tepsiler de bakır malzemeden yapılmış ekipmanlardan oluşmaktaydı. Daha kalabalık nüfuslu evlerde ve düğün, bayram gibi ritüel yemeklerin pişirilmesinde büyük kara kazanlar ve helvane tencereler kullanılmıştır. Günümüzde ise evlerde yemek pişirmek için çelik ve teflon tencereler kullanılmaktadır. Bakırdan yapılmış ekipman kullanımı oldukça azalmıştır.

(2) Yörede En Çok Tüketilen Besin Grupları: Yenice yöresinde eskiden günümüze kadar olan süreçte en çok tüketilen besinler ot ve sebzelerdir. Yöre mutfağının olmazsa olmazı Mancardır (Karalahana). Yapılan görüşmelerde pazı, ısırgan otu, ebegümeci, madımak, tekesakalı, yemlik, toklamaç, labada gibi yeşil otlardan bahsedilse de yemek malzemesi olarak en çok Mancarın (Karalahana) tercih edildiği tespit edilmiştir. Mancar tüketiminin fazla olmasının nedeni, otun hem yazın hem de kışın kolaylıkla erişilebilir olmasıdır. Yöre mutfağında bakliyat olarak en çok 
bakla ve mısır göcesi (mısır yarması, kırılmış mısır) kullanılmaktadır. Canbulat (2014) Yenice mutfağının et ve hububat bakımından fakir olmasına rağmen, bakladan tatlı yapılmasını şaşkınlıkla karşıladığını belirtmektedir.

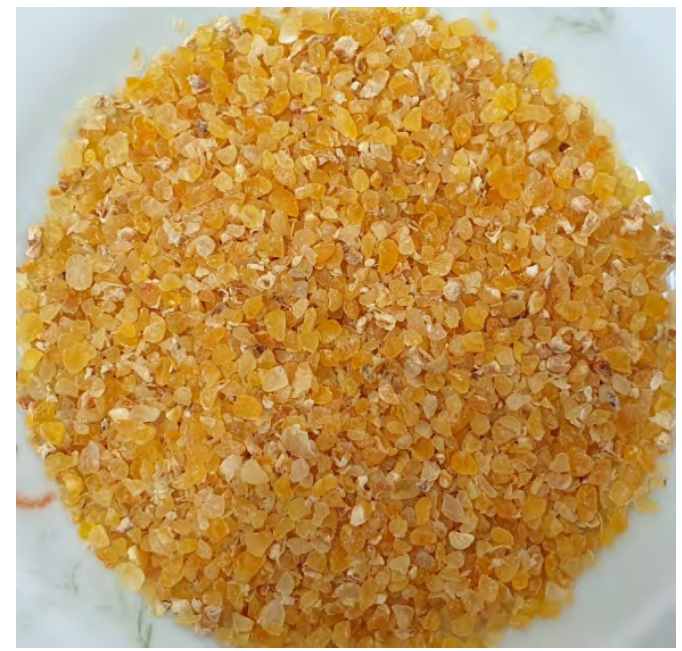

Fotoğraf 1. Misır Göcesi

(Kaynak: Araştırmacılar tarafından fotoğraflanmıştır)

Yenice yöresinde doğal olarak yetişen pek çok yabani mantar türü bulunmaktadır. Yöre halkının çoğunlukla mantarları kendilerinin doğadan topladığı, bazen de çok pahalı olmasına rağmen (et fiyatı olarak ifade edilmiştir) halk pazarından satın aldıkları belirlenmiştir. Bu durum mantarın yöre mutfağındaki önemini ortaya koymaktadır. Bu bağlamda; yöre mutfağında kullanılan gıda malzemelerinin vegan beslenme için oldukça uygun olduğu görülmektedir.

(3) Yörede En Çok Tüketilen Baharat Türleri: Yöre kadınları ile yapılan görüşmede mutfaklarda çoğunlukla kırmızıbiber, karabiber, nane kullandıkları tespit edilmiştir. Karabiberi dışarıdan satın almakta, kendi bahçelerinde yetiştirdikleri kırmızıbiberi (Arnavut biberinden) ve naneyi kurutma, parçalama ve ovma işlemlerinden geçirerek kullanmaktadırlar. K3 ve K7, yemeklerde baharat kullanımını aşağıdaki gibi açıklamaktadır:

"Yemeklerimiz zaten ot ve bitki ăğrlikl. Bunların kendine has reyhanları (kokuları) var, fazla baharat kullanmaya gerek kalmıyor"

(4) Yörede En Çok Tüketilen Yağ Türü: Yenice mutfaklarında günümüzde en çok ayçiçek yağının kullanıldığı tespit edilmiştir. Mutfaklarda zeytinyağı ve margarin kullanımına pek rastlanmamaktadır. Eskiden ayçiçek yağı yanı sıra yemeklerde tereyağı da kullanılmaktaydı. Fakat tereyağı yörenin mutfak kültüründe önemli bir yere sahip değildir. Yemeğin pişirilmesi sırasında yağ genellikle soğanının kavrulması (karamelize edilmesi) için kullanılmaktadır. Ayrıca katılımcıların pişirmiş olduğu yemeklerin tadımına ve pişirme sırasındaki gözlemlere dayanarak, yöre yemeklerinin çok yağlı olmadıkları tespit edilmiştir. Katılımcılar yağı yemekleri lezzetlendirmek için kullanmaktadırlar.

Yörede Pişirilen Yemekler: Araştırmanın ikinci teması Yenice mutfağında yapılan yemekleri belirlemeyi amaçlamaktadır. Bu temada yer alan beş kod ve elde edilen bulgular aşağıda maddeler halinde verilmiştir.

(1) Yöreye Özgü Sebze ve Meyve Yemekleri: Yenice halkının çoğu bahçesinde ot ve sebze yetiştirmektedir. Taze fasulye, taze bakla ve kendiliğinden yetişen mantar yörenin karakteristik besinleridir. Taze fasulyeden "Uzun Fasulye" adlı yemek pişirilmektedir. Uzun fasulye, 
bahçeden toplanan fasulyelerin uç kısımları temizlendikten sonra kırılmadan uzun bir şekilde çok az su ile haşlanması, sonrasında üzerine kızgın yağ dökülmesi ile hazırlanan bir yemektir. Bu yemek, yufkaya sarılarak veya tercihen üzerine sarımsaklı yoğurt dökülerek tüketilmektedir.

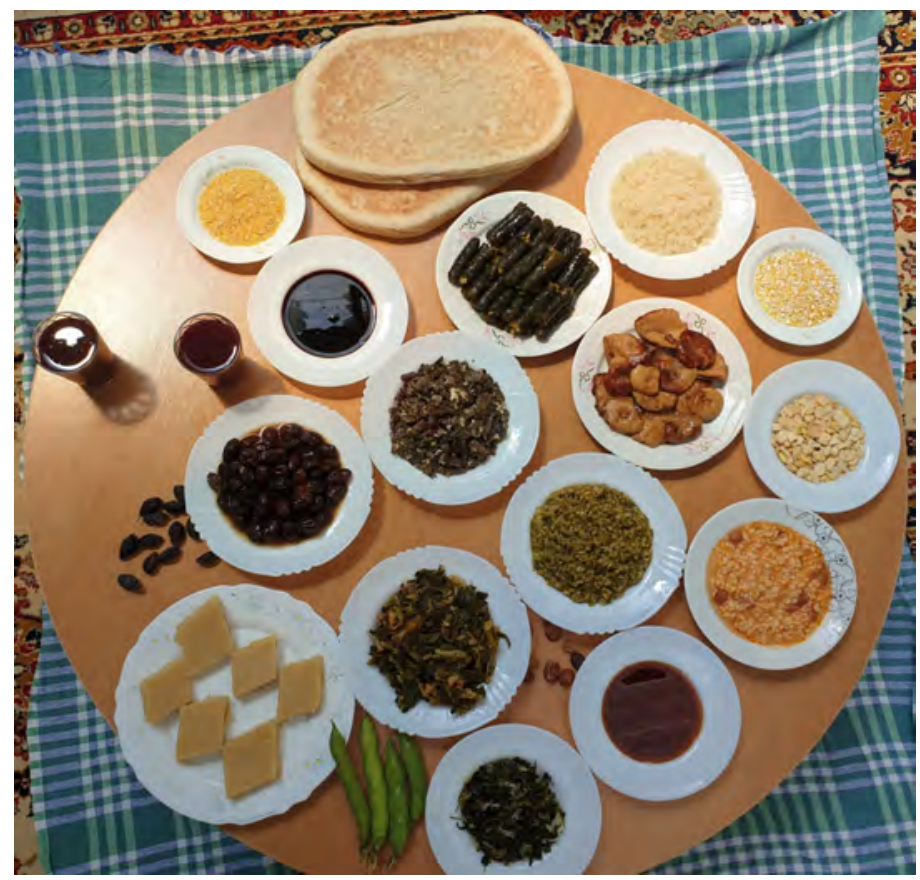

Fotoğraf 2. Yenice Vegan mutfağ1

(Kaynak: Araştırmacılar tarafından fotoğraflanmıştır)

Bölgenin en önemli sebzelerinden biri olan taze bakladan (Sultani Bakla-Fotoğraf 3) da "Sultani salatası" yapılmaktadır. Sultani salatası eskiden yalnızca suda haşlanarak, sarmısaklı yoğurt ilavesi ile tüketilen yağsız bir yemektir. Fakat günümüzde bu salata, haşlanmış baklanın yağ ve soğan ile kavrulmasıyla hazırlanmaktadır.

Bu sebzelerin dışında yörede, kabak, domates, salatalık, biber, dolma biber, patlıcan gibi sebzeler de yetiştirilmekte ve mutfaklarda kullanılmaktadır. Bu sebzeler taze olarak tüketilmesinin yanı sıra kışlık kullanım için de kurutularak saklanmaktadır. Sebzelerden taze fasulye, taze bakla, patlıcan, biber, dolmalık biber, meyvelerden de elma, armut, ahlat, ayva, erik, mürdümeriği, vişne, kızılcık ve kuşburnu kurutularak kış için saklanmaktadır. Kurutulmuş olan meyvelerden kışın hoşaf yapılmaktadır. Ovaz (Fotoğraf 4) yöre mutfağında önemli bir yere sahiptir. Bu meyveden yapılan "Şaptak" tatlısına Yöreye Özgü Vegan Tatlı Çeşitleri başlığında yer verilmiştir.

Yenice mutfağında elma sirkesinin de oldukça önemli bir yeri vardır. Özellikle acı elma sirkesi salatalara lezzet verir, hatta sirkesiz salata yenmez.

Mantarın geniş bir kullanım alanı bulduğu Yenice mutfağında mantarın kavurması, yemeği ve böreği yapılmaktadır. Sonbaharda Kanlıca mantarı, baharda ise Ebişke mantarının Yenice mutfağında önemli bir yeri vardır. Mantar ve mısır ile yapılan mantar çorbası yörede oldukça rağbet gören bir yemektir. Yenice mutfak kültürüne özgü diğer sebze yemekleri ise; Pırasa (göce ile pişirilir), Pazı, Pazı kavurması, Acı mantar kızartması, Acı mantar kavurması, acı mantar közlemesi ve kurutulmuş taze fasulye yemeğidir. 


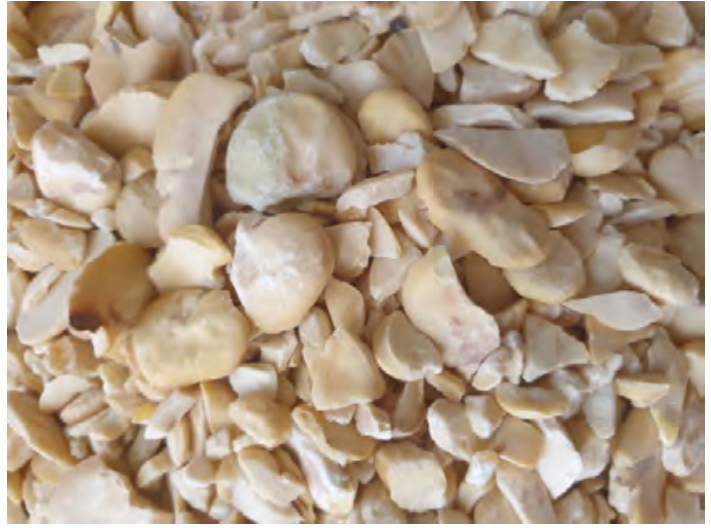

Fotoğraf 3. Bakla

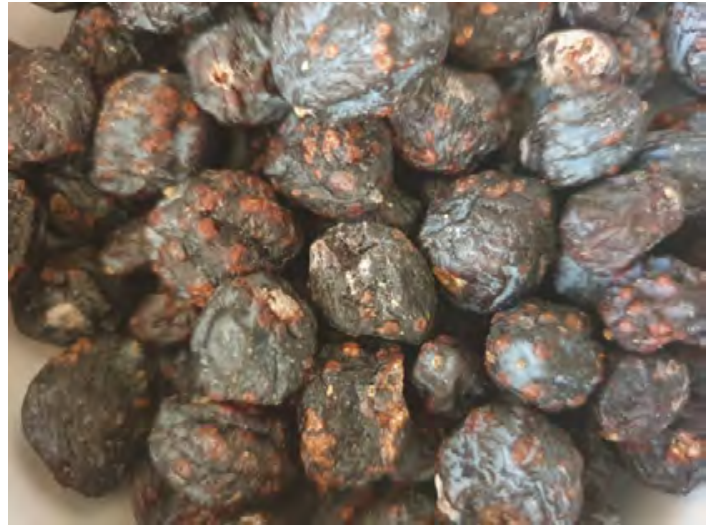

Fotoğraf 4. Kurutulmuş Ovaz

(Kaynak: Araştırmacılar tarafından fotoğraflanmıştır)

Hamur işlerinden gözleme ve börekler aralarına çeşitli mantar, sebze ve otlardan hazırlanan iç konularak pişirilmektedir. Yörede yapılan bal kabağı böreği bu hamur işlerinin güzel bir örneğidir. Katılımcıların verdiği tarife göre; bal kabağı rendelenerek soğanla kavrulur. Daha sonra açılmış hamurun içerisine konularak saçta pişirilir. Eskiden bu kabağın içine ceviz, bazen de şeker ilave edildiği belirlenmiştir. Fakat günümüzde ceviz veya şeker ilavesi pek tercih edilmemektedir. Önemli bir sebzeli hamur işi de mantarlı gözlemedir. Mantarın, soğan ve baharatlar ile kavrulduktan sonra açılmış börek yufkasının içine konularak, saçta pişirilmesi ile hazırlanır. Yöre mutfağında bulunan bu sebzeli yemekler, Yenice'nin vegan mutfağı bakımından ne kadar zengin olduğunu göstermektedir.

(2) Yöreye Özgü Ot Yemekleri: Yöre mutfağına hakim olan otlar başta Mancar (karalahana) ve ıspıt otu olmak üzere; en çok ısırgan otu, pazı, semizotu, ebegümeci, hindiba, madımak, teke sakalı, yemlik, labadadır (Bkz. Fotoğraf 5). Özellikle bahar aylarında kendiliğinden yetişen otlar yemek yapımında ya tek başına ya da diğer otlar ile birleştirilerek kullanılmaktadır. Örneğin; Mancar (Karalahana) yemeği (Standart Reçete 1) pişirilirken mevsiminde bulunan karakabak, pırasa, pazı, havuç, ısırgan otu, ebegümeci gibi ot ve sebzelerden biri ya da birkaçı da mutlaka yemeğe eklenmektedir. Bu durum Mancar otundan yapılan yemeklerin oldukça zengin besin değerlerine sahip olduğunu düşündürmektedir. Yörede Mancar (Karalahana) otundan, Mancar kavurması, Mancar yemeği (Standart Reçete 1) ve Mancar dolması-Karadolma (Standart Reçete 2) yemekleri yapılmaktadır. Bu yemeklerin gerek günlük yaşamda gerekse ritüel sofralarında oldukça fazla tüketildiği tespit edilmiştir. Yöreye özgü Mancar yemeklerinin standart reçeteleri aşağıda sunulmaktadır. 


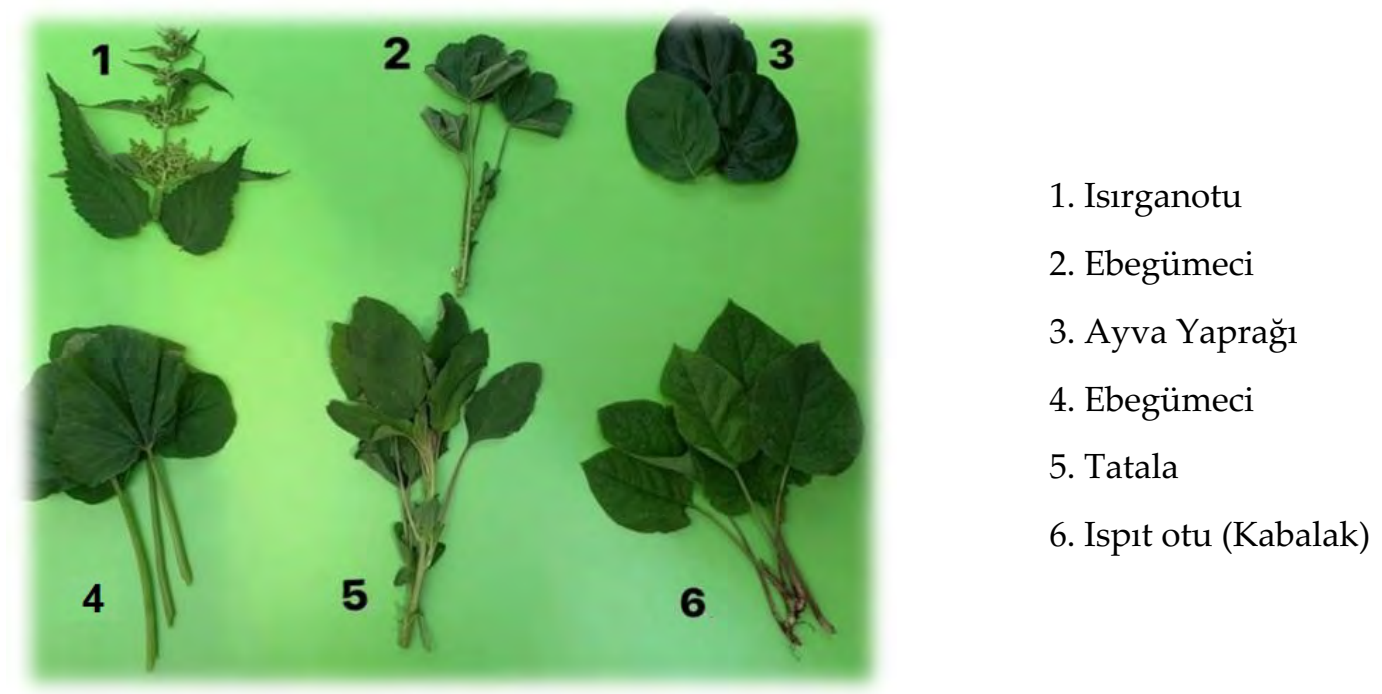

Fotoğraf 5. Yenice'de yemek yapımında kullanılan otlar

(Kaynak: Araştırmacılar tarafından fotoğraflanmıştır)

Standart Reçete 1. Mancar Yemeği ${ }^{1}$

\begin{tabular}{|c|c|c|c|}
\hline \multicolumn{3}{|c|}{ Reçete: Mancar Yemeği } & Standart Reçete No:1 \\
\hline \multicolumn{4}{|c|}{$\begin{array}{l}\text { Miktar: } 4 \text { Porsiyon } \\
\text { Porsiyon Büyüklü̆g̈ü: } 200 \text { gr. } \\
\text { Hazırlama Süresi: } 30 \mathrm{dk} \text {. } \\
\text { Pişirme Süresi: } 35 \mathrm{dk} . \\
\text { Toplam Maliyet: } 12,9 \mathrm{TL} \\
\text { Porsiyon Başına Maliyet: 3,2 TL }\end{array}$} \\
\hline Malzemeler & Miktar & Maliyet & Yapılışı \\
\hline $\begin{array}{l}\text { Mancar } \\
\text { (Karalahana) }\end{array}$ & $1 \mathrm{~kg}$ & $5 \mathrm{TL}$ & \multirow{10}{*}{$\begin{array}{l}\text { *Kuru fasulye veya barbunya akşamdan suya } \\
\text { konulur. Pişirme öncesi biraz haşlanır. } \\
{ }^{*} \text { Geniş bir tencerede Mancar haşlanır. } \\
\text { *Soğan ince ince doğranır ve kavrulur, salçası } \\
\text { ilave edilir. } \\
\text { *İnce kıyılmış havuç, kabak ve diğer malzemeler } \\
\text { büyük bir tencereye alınır, yumuşak hale } \\
\text { gelinceye kadar pişirilir. } \\
\text { *Dinlendirildikten sonra servis edilir. }\end{array}$} \\
\hline Kuru Soğan & 2 adet & $1,7 \mathrm{TL}$ & \\
\hline Kuru Fasulye & $150 \mathrm{gr}$ & $1,2 \mathrm{TL}$ & \\
\hline Göce (Misir) & $100 \mathrm{gr}$ & $2,1 \mathrm{TL}$ & \\
\hline Havuç & $100 \mathrm{gr}$ & $0,4 \mathrm{TL}$ & \\
\hline Kara Kabak & $100 \mathrm{gr}$ & $0,4 \mathrm{TL}$ & \\
\hline \multicolumn{3}{|c|}{ İstenirse mevsim otları da kullanılabilir. } & \\
\hline Salça & $40 \mathrm{gr}$ & $0,7 \mathrm{TL}$ & \\
\hline Sivi yağ & $40 \mathrm{gr}$ & $1,4 \mathrm{TL}$ & \\
\hline Tuz & & - & \\
\hline
\end{tabular}

${ }^{1}$ Standart Reçete 1- 10'da yer alan yemek fotoğraflar yazarlar tarafından çekilmiştir. 
Standart Reçete 2. Mancar Dolması (Karadolma)

\begin{tabular}{|c|c|c|c|}
\hline \multicolumn{4}{|c|}{ Reçete: Mancar Dolması (Karadolma) } \\
\hline \multicolumn{4}{|c|}{$\begin{array}{l}\text { Miktar: } 4 \text { Porsiyon } \\
\text { Porsiyon Büyüklüğ̈̈: } 200 \text { gr. } \\
\text { Hazırlama Süresi: } 45 \mathrm{dk} \text {. } \\
\text { Pişirme Süresi: } 30 \mathrm{dk} . \\
\text { Toplam Maliyet: } 29,5 \mathrm{TL} \\
\text { Porsiyon Başına Maliyet: 7,4 TL }\end{array}$} \\
\hline Malzemeler & Miktar & Maliyet & Yapılışı \\
\hline Karalahana (Mancar) & Üç bağ & $9 \mathrm{TL}$ & \multirow{9}{*}{$\begin{array}{l}\text { *Karalahanalar kaynar suda 3-5 dk. haşlanır. } \\
\text { *Kuru soğan küp küp doğranır ve kavrulur. } \\
\text { *Salça, ince kıyılmış maydanoz, pirinç, bulgur } \\
\text { ve baharatlar birlikte bir su bardağı su ile } \\
\text { pişirilir. } \\
\text { ×Karalahana yaprakları hazırlanmış iç ile } \\
\text { doldurularak sarılır. } \\
\text { *Tencerenin altına karalahana sapları dizilir, } \\
\text { üzerine de sarılmış dolmalar yerleştirilir. } \\
\text { *Üzeri bir düz tabakla örtülür, } 400 \text { gr kaynar } \\
\text { su ilave edilerek kısık atește pişirilir. }\end{array}$} \\
\hline Kuru Soğan & 3 adet & $1,5 \mathrm{TL}$ & \\
\hline Pirinç & $360 \mathrm{gr}$ & $6 \mathrm{TL}$ & \\
\hline Bulgur & $320 \mathrm{gr}$ & $4,5 \mathrm{TL}$ & \\
\hline Siviyağ & $300 \mathrm{gr}$ & $2,4 \mathrm{TL}$ & \\
\hline Salça & $160 \mathrm{gr}$ & $4 \mathrm{TL}$ & \\
\hline Maydonoz & Bir bağ & $1,5 \mathrm{TL}$ & \\
\hline Tuz & $8 \mathrm{gr}$ & $0,6 \mathrm{TL}$ & \\
\hline Karabiber ve Pulbiber & - & - & \\
\hline
\end{tabular}

K2 eskiden annesinin yöre otlarını mısır ekmeği yapımında da kullandığından bahsetmiştir.

"Annem yokluk dönemlerinde mancar, ısırgan otu ve kabalak otunu mısır unuyla yoğurur, sonra dışarıdaki ocakta pişirirmiş. Fakat günümüzde sadece ısırgan otu nadir de olsa mısır ekmeği yapıminda kullanilmaktadır."

Mancar otundan sonra Yenice mutfağında sıklıkla kullanılan diğer bir ot Ispit otudur. Kabalak otu olarak da bilinen ıspıt otunun yörede kavurması yapılmaktadır.

Ebegümeci, mancar yemeğinin içine konulmasının yanı sıra yaprakları kaynatılarak içilir. Ebegümeci çayının boğaz enfeksiyonuna iyi geldiği belirtilmektedir. Ayrıca kurutulmuş ısırgan otu ve ayva yaprağı da yörede çay gibi demlenerek içilmektedir. Soğan ile birlikte kavrularak pişirilen "Tatala" otu yemeği de Yenice yöresi sofralarının önemli bir vegan yemeğidir. Bahçelerde yetiştirilen pazı, taze fasulye yaprağı ve dut ağacı yaprağı dolma yapımında kullanılmaktadır. Fakat bu yemeklerin tarihinin çok eski olmadığı, yöreye gelen misafirlerden veya yabancılardan öğrenildiği belirlenmiştir.

(3) Yöreye Özgü Tahıl ve Kurubaklagil Yemekleri: Yenice mutfak kültüründe tahıl olarak mısır, mısır göcesi, buğday, pirinç ve bulgur kullanılmaktadır. Dolma ve sarma yemeklerinde bulgur ve pirinç birlikte karıştırılarak kullanılırken, göce çorbası (Standart Reçete 4) ve mancar yemeğinde çoğunlukla mısır göcesi kullanılmaktadır. Eskiden dolma yapımında bulgur ve pirinç yerine göce kullanılmaktaydı. 
Standart Reçete 3. Ispıt Otu Kavurması

\begin{tabular}{|c|c|c|c|}
\hline \multicolumn{3}{|c|}{ Reçete: Ispit Otu Kavurması } & Standart Reçete No: 3 \\
\hline \multicolumn{3}{|c|}{$\begin{array}{l}\text { Miktar: } 4 \text { Porsiyon } \\
\text { Porsiyon Büyüklüğ̈ü: } 200 \mathrm{gr} . \\
\text { Hazırlama Süresi: } 30 \mathrm{dk} . \\
\text { Pişirme Süresi: } 35 \mathrm{dk} . \\
\text { Toplam Maliyet: } 23,8 \mathrm{TL} \\
\text { Porsiyon Başına Maliyet: 5,9 TL }\end{array}$} & \\
\hline Malzemeler & Miktar & Maliyet & Yapılışı \\
\hline $\begin{array}{l}\text { Ispit Otu } \\
\text { (Kabalak) }\end{array}$ & 2 Bağ & $20 \mathrm{TL}$ & \multirow{5}{*}{$\begin{array}{l}\text { *Ispıt otu yıkanır ve doğranır. } \\
\text { *Geniş bir tencerede kaynar su ilave edilerek haşlanır. } \\
\text { *Soğan ince ince doğranır ve kavrulur salçası katılarak } \\
\text { Ispıt otu ilave edilir. Yaklaşık } 8-10 \mathrm{dk} \text {. kavurulur. } \\
\text { *Dinlendirildikten sonra servis edilir. Tercihen } \\
\text { pişirirken içine yumurta veya sonrasında üzerine } \\
\text { sarımsaklı yoğurt ilave edilebilir. }\end{array}$} \\
\hline Kuru Soğan & 2 adet & $1,7 \mathrm{TL}$ & \\
\hline Salça & $40 \mathrm{gr}$ & $0,7 \mathrm{TL}$ & \\
\hline Siv1 yağ & $40 \mathrm{gr}$ & $1,4 \mathrm{TL}$ & \\
\hline Tuz & - & - & \\
\hline
\end{tabular}

Standart Reçete 4. Göce Çorbası

\begin{tabular}{|c|c|c|c|}
\hline \multicolumn{3}{|c|}{ Reçete: Göce Çorbası } & Standart Reçete No: 4 \\
\hline \multicolumn{3}{|c|}{$\begin{array}{l}\text { Miktar: } 5 \text { Porsiyon } \\
\text { Porsiyon Büyüklüğü: } 180 \text { gr. } \\
\text { Hazırlama Süresi: } 20 \mathrm{dk} . \\
\text { Pişirme Süresi: } 45 \mathrm{dk} . \\
\text { Toplam Maliyet: } 6,9 \mathrm{TL} \\
\text { Porsiyon Başına Maliyet: 1,4 TL }\end{array}$} & 3 \\
\hline Malzeme & Miktar & Maliyet & Yapı11şı \\
\hline Misır Göcesi & $150 \mathrm{gr}$ & $1,5 \mathrm{TL}$ & \multirow{8}{*}{$\begin{array}{l}\text { *İnce kıyılan soğan yă̆ ile kavrulurken üzerine salça } \\
\text { eklenir. } \\
\text { *İçerisine haşlanmış göce eklenerek } 1-2 \text { dk } \\
\text { kavrulmaya devam edilir. } \\
{ }^{*} \text { Kıvam arttırmak için nişasta su ile iyice çırpılarak } \\
\text { tüm malzemeler ile birlikte karıştırılır. } \\
\text { *Taneli malzemelerin pişmesiyle çorba dinlenmeye } \\
\text { bırakılır. }\end{array}$} \\
\hline Bakla & $150 \mathrm{gr}$ & $1,8 \mathrm{TL}$ & \\
\hline Soğan & 1 adet & $0,5 \mathrm{TL}$ & \\
\hline Siviyağ & $50 \mathrm{gr}$ & $0,8 \mathrm{TL}$ & \\
\hline Salça & $50 \mathrm{gr}$ & $1,2 \mathrm{TL}$ & \\
\hline Nişasta & $45 \mathrm{gr}$ & $1,1 \mathrm{TL}$ & \\
\hline $\mathrm{Su}$ & $1 \mathrm{~kg}$ & - & \\
\hline Tuz & - & - & \\
\hline
\end{tabular}


Yenice mutfağında baklanın kullanım alanı oldukça geniştir. Taze bakla (Sultani bakla) yemeklerde; sultani bakla salatası ve taze bakla yemeği yapımında kullanılmaktadır. Kuru bakla ise tatlı yapımında kullanılmakta, leblebi gibi kuru yemiş olarak tüketilmektedir. Bunun yanı sıra; bakla haşlanıp sonrasında kestane gibi kavurularak da tüketilmektedir. Yörede yapılan aşure çorbası da önemli bir tahıl ve kurubaklagil yemeğidir, vegan tatlılar bölümünde ayrıntıları ile incelenmiştir.

Malay (Standart Reçete 5) eskiden ekmeğin olmadığı zamanlarda yapılan bir yemektir. Günümüzde de halen mutfaktaki önemini koruyan Malay, en çok kış aylarında tüketilmektedir. Yağ veya pekmeze alternatif olarak ciğer ve tereyağı da kullanılabilmektedir.

Standart Reçete 5. Malay

\begin{tabular}{|c|c|c|c|}
\hline \multicolumn{3}{|c|}{ Reçete: Malay (Koyu Çorba) } & Standart Reçete No:5 \\
\hline \multicolumn{3}{|c|}{$\begin{array}{l}\text { Miktar: } 4 \text { Porsiyon } \\
\text { Porsiyon Büyüklüğ̈̈: } 180 \text { gr. } \\
\text { Hazırlama Süresi: } 10 \mathrm{dk} . \\
\text { Pişirme Süresi: } 12 \mathrm{dk} . \\
\text { Toplam Maliyet: } 4,2 \mathrm{TL} \\
\text { Porsiyon Başına Maliyet: 1,05 TL }\end{array}$} & 8 \\
\hline Malzemeler & Miktar & Maliyet & \\
\hline Misir unu & $400 \mathrm{gr}$ & $2,4 \mathrm{TL}$ & \multirow{4}{*}{$\begin{array}{l}\text { Yapıışı } \\
\text { *Tencereye su konularak kaynatılır. } \\
\text { *Un yavaş yavaş kaynayan suya ilave edilir ve } \\
\text { topaklanmayı önleyecek şekilde sürekli olarak bir } \\
\text { oklava ile karıştırır. } \\
\text { *Oldukça koyu bir muhallebi kıvamı elde } \\
\text { edildikten sonra hamur islatılmış kaşık ile kaşı } \\
\text { kaşık tabağa alınır. Üzerine kızdırılmış yağ } \\
\text { (istenirse pekmez) gezdirilir. }\end{array}$} \\
\hline Siv1 yağ & $80 \mathrm{gr}$ & $1,8 \mathrm{TL}$ & \\
\hline $\mathrm{Su}$ & $1 \mathrm{lt}$ & - & \\
\hline & & & \\
\hline
\end{tabular}

Yöre mutfağına ait olan Köfter çorbası farklı bir hamur işi yemeğidir. Köfter çorbasının tarifi Standart Reçete 6'da verilmektedir. 
Standart Reçete 6. Köfter Çorbası

\begin{tabular}{|c|c|c|c|}
\hline \multicolumn{3}{|c|}{ Reçete: Köfter Çorbası } & Standart Reçete No:6 \\
\hline \multicolumn{4}{|c|}{$\begin{array}{l}\text { Miktar: } 4 \text { Porsiyon } \\
\text { Porsiyon Büyüklüğü: } 180 \mathrm{gr} \text {. } \\
\text { Hazırlama Süresi: } 50 \mathrm{dk} \text {. } \\
\text { Pişirme Süresi: } 20 \mathrm{dk} . \\
\text { Toplam Maliyet: } 4,8 \mathrm{TL} \\
\text { Porsiyon Başına Maliyet: 1,2 TL }\end{array}$} \\
\hline Malzemeler & Miktar & Maliyet & \multirow{9}{*}{$\begin{array}{l}\text { Yapılışı } \\
\text { *Un, tuz su ile yoğurulur. Hamur kalın yufka } \\
\text { halinde açılarak, erişteden daha kalın bir şekilde } \\
\text { gelişigüzel kesilir. } \\
\text { *Kesilen hamurlar } 1 \text { lt kaynar suya baharatlar ile } \\
\text { birlikte atılır. } \\
\text { *Ince kıyılan soğan yağ ile kavrulur, üzerine salça } \\
\text { konulur, kaynayan hamurlu suya kavrulmuş } \\
\text { soğan ilave edilir, baharat katılarak servis edilir. }\end{array}$} \\
\hline Un & $360 \mathrm{gr}$ & $1,5 \mathrm{TL}$ & \\
\hline Soğan & 1 adet & $0,5 \mathrm{TL}$ & \\
\hline Siviyağ & $50 \mathrm{gr}$ & $0,8 \mathrm{TL}$ & \\
\hline Salça & $50 \mathrm{gr}$ & $1,2 \mathrm{TL}$ & \\
\hline $\mathrm{Su}$ & $900 \mathrm{gr}$ & - & \\
\hline Tuz & $4 \mathrm{gr}$ & - & \\
\hline Karabiber & $3 \mathrm{gr}$ & - & \\
\hline & & & \\
\hline
\end{tabular}

(4) Yöreye Özgü Vegan Tatlı Çeşitleri: Yenice yöresine özgü tatlılarda genellikle kurubaklagil ve tahıllar kullanılmaktadır. Sultani (Kocabaklava) Tatlısı, Aşure, Nişasta Helvası ve Şaptak tatlıları Yenice'ye özgü tatlı çeşitleridir. Vegan nitelikteki bu tatlıların standart reçeteleri aşağıda verilmektedir.

Standart Reçete 7. Şaptak (Ovaz Tatlısı)

\begin{tabular}{|c|c|c|c|}
\hline \multicolumn{3}{|c|}{ Reçete: Şaptak (Ovaz Tatlısı) } & Standart Reçete No:7 \\
\hline \multicolumn{3}{|c|}{$\begin{array}{l}\text { Miktar: } 4 \text { Porsiyon } \\
\text { Porsiyon Büyüklüğü: } 180 \text { gr. } \\
\text { Hazırlama Süresi: Bir hafta } \\
\text { Pişirme Süresi: } 20 \mathrm{dk} . \\
\text { Toplam Maliyet: } 4,9 \mathrm{TL} \\
\text { Porsiyon Başına Maliyet: 1,2 TL }\end{array}$} & $x_{i}$ \\
\hline Malzemeler & Miktar & Maliyet & Yapılışı \\
\hline Ovaz tozu & $350 \mathrm{gr}$ & $1,5 \mathrm{TL}$ & \multirow{3}{*}{$\begin{array}{l}\text { *Taş değirmende çekilip, irmik haline getirilen } \\
\text { ovaz meyvesi şeker ve sıcak su katılarak } \\
\text { marmelat haline getirilir. Genellikle ekmek } \\
\text { banarak tüketilir. }\end{array}$} \\
\hline Şeker & $180 \mathrm{gr}$ & $0,5 \mathrm{TL}$ & \\
\hline $\mathrm{Su}$ & $50 \mathrm{gr}$ & $0,8 \mathrm{TL}$ & \\
\hline
\end{tabular}


Ovaz tatlısının hazırlık aşaması oldukça meşakkatli bir uğraş gerekmektedir. Eskiden yöre halkı bu meyveleri ormandan toplamakta iken, günümüzde halk pazarlarından satın almaktadırlar. Katılımcılardan K2 konuyla ilgili bilgisini şu şekilde paylaşmıştır.

"Pazarlardan aldığımız Ovaz meyvelerini kuru bir ortamda tutarak kahverengi hale gelmesini bekleriz. Kahverengi hale gelen meyveler yıkandıktan sonra ahşap havanda ahşap ekipmanlar (soku) ile dövülerek ezilir. Hamur haline getirilen meyveler patates büyüklü̈̆̈̈nde el ile şekillendirilerek büyük tepsilere konulur. Ters düz edilerek yaklaşık bir hafta güneşte kurutulur. Sonra da çekilmesi için (irmik büyüklü̈̆̈̈nde) taş değirmenlere gönderilir. Su ile marmelat kıvamına getirilir, çoğunlukla ekmekle veya kaşık ile yenir. Genellikle öğlen ve akşam yemeklerinde tüketilir."

Yöreye özgü diğer tatlı çeşidi Koca Baklava, Pekmezli Bakla olarak da isimlendirilen Sultani Tatlısıdır. Tatlının ana malzemesi bakladır. Koca bakla (eşek baklası olarak da bilinir) kabukları ayıklanıp temizlendikten sonra kurutulur. Taş değirmenlerde çekilen bakla küçük parçalara ayrılır. Böylece yemek ve tatlı yapımı için hazır hale gelmiş olur. Katılımcılardan K4 tatlının yapılışı tartışılırken bazı püf noktalarına değinmiştir.

"Baklalar karardıkları için sıcak suya konulmaz, mutlaka soğuk su kullanmalıdır. Tatlının yapımında günümüzde şeker kullanılmaktadır, fakat eskiden tatlandırmak için şeker yerine elma, ahlat, dut veya armut pekmezi kullanilmaktaydr."

Standart Reçete 8. Sultani (Kocabaklava) Tatlısı

\begin{tabular}{|c|c|c|c|}
\hline \multicolumn{3}{|c|}{ Reçete: Sultani (Kocabaklava) Tatlısı } & Standart Reçete No:8 \\
\hline \multicolumn{4}{|c|}{$\begin{array}{l}\text { Miktar: } 4 \text { Porsiyon } \\
\text { Porsiyon Büyüklüğü: } 180 \text { gr. } \\
\text { Hazırlama Süresi: } 30 \mathrm{dk} . \\
\text { Pişirme Süresi: } 30 \mathrm{dk} . \\
\text { Toplam Maliyet: } 12,7 \mathrm{TL} \\
\text { Porsiyon Başına Maliyet: 3,2 TL }\end{array}$} \\
\hline Malzemeler & Miktar & Maliyet & Yapılışı \\
\hline Bakla & $600 \mathrm{gr}$ & $9,9 \mathrm{TL}$ & \multirow{4}{*}{$\begin{array}{l}\text { *Baklalar akşamdan soğuk su ile ıslatılır, sabah yeni su } \\
\text { ile haşlanır, sürekli olarak suyun üzerindeki köpükler } \\
\text { temizlenir. } \\
\text { *Suyu süzülerek tekrar soğuk su ilave edilerek } \\
\text { kaynatılır, bu işlem birkaç kez tekrarlanabilir. } \\
\text { *Haşlanmış patates kıvamıı alır almaz şekeri eklenir } \\
\text { ve iyice püremsi hale getirilip tepsiye dökülür. } \\
\text { Soğuduktan sonra dilimlenerek servis edilir. }\end{array}$} \\
\hline Şeker & $450 \mathrm{gr}$ & $2,8 \mathrm{TL}$ & \\
\hline Su & $2,5 \mathrm{~kg}$ & - & \\
\hline & & & \\
\hline
\end{tabular}

Özellikle ritüellerde yapılan yöreye özgü bir diğer tatlı çeşidi ise Nişasta helvasıdır. İsteğe bağlı olarak Tereyağı da konulabilen nişasta helvasının standart reçetesi aşağıda verilmektedir. 
Standart Reçete 9. Nişasta Helvası

\begin{tabular}{|c|c|c|c|}
\hline \multicolumn{3}{|c|}{ Reçete: Nişasta Helvası } & Standart Reçete No:9 \\
\hline \multicolumn{4}{|c|}{$\begin{array}{l}\text { Miktar: } 4 \text { Porsiyon } \\
\text { Porsiyon Büyüklüğü: } 200 \text { gr. } \\
\text { Hazırlama Süresi: } 30 \mathrm{dk} \text {. } \\
\text { Pişirme Süresi: } 30 \mathrm{dk} . \\
\text { Toplam Maliyet: } 15,7 \mathrm{TL} \\
\text { Porsiyon Başına Maliyet: 3,9 TL }\end{array}$} \\
\hline Malzemeler & Miktar & Maliyet & Yapılışı \\
\hline $\begin{array}{l}\text { Buğday } \\
\text { Nişastası }\end{array}$ & $380 \mathrm{gr}$ & $6 \mathrm{TL}$ & \multirow{4}{*}{$\begin{array}{l}\text { *Nişasta ve toz şeker bir miktar suyla karıştırılarak } \\
\text { boza kıvamına getirilir, yağ eklenir. } \\
\text { *Ocağa konulan tencerede nişastanın topaklanmaması } \\
\text { için iyice ezilerek } 20 \mathrm{dk} \text {. karıştırılır. } \\
\text { *Dinlenmeye bırakılır, sonrasında ise servis edilir. }\end{array}$} \\
\hline Siviyağ & $180 \mathrm{gr}$ & $7 \mathrm{TL}$ & \\
\hline Şeker & $450 \mathrm{gr}$ & $2,7 \mathrm{TL}$ & \\
\hline $\mathrm{Su}$ & - & - & \\
\hline
\end{tabular}

Yenice'ye özgü Aşure çorbası olarak adlandırılan bu yiyecek esasen bir kurubaklagil tatlısıdır. Katılımcılardan K7 Aşure çorbası hakkında şu bilgileri vermektedir:

"Eskiden aşuremiz hem tatlı hem de tuzlu olmak üzere iki şekilde yapılırdı. Çorba denilmesinin nedeni kıvamının çorba şeklinde olmasıdır. Eskiden daha çok tuzlu aşure yapılırdı, kemikle (boyun ve sırt kemiği ile) pişirilir ve sıcak sıcak yenirdi. Kemik önceden haşlanırdl, ayrı bir yerde haşlanmış olan nohut, kuru fasulye ve buğday ile tekrar farklı bir tencerede pişirilirdi. Şimdilerde şekerli yaparız aşureyi, tuzlu yiyen artık kalmadı, pişiren de pek kalmadı".

Şeker ile yapılan Aşure çorbasının standart reçetesi aşağıda verilmektedir.

(5) Yenice Yöresine Ait Ritüel Yemekleri: Aşağıda Yenice'de geçmişte ve günümüzde bayram, düğün vb. önemli günlerde yapılan yemeklere yer verilmiştir.

Bayram Yemekleri: Yörede bayramların özellikle Kurban Bayramının olmazsa olmaz yemeği mancar (karalahana) dolmasıdır. Katılımcılardan K5 ve K7 bu durumu "Mancar dolması olmazsa dernek olmaz" şeklinde ifade etmiştir. Ayrıca pazı ve çükündür (kırmızı pancar) ile pişirilen "Çükündür yemeği" de bayramların önemli yemeklerindendir. Eğer mevsim otları veya sebzeleri (ısırgan otu, mancar, ıspanak, pırasa vb.) varsa mutlaka çükündür yemeğine katılmaktadır. Ayrıca kuru fasulye ile yapılan mısır çorbası, yeşil salata (marul salatası) ve cacık bayramlarda sofralarda bulunan diğer yemeklerdir. Tatlılardan sultani bakla tatlısı, lokma, baklava ve nişasta helvasının yapıldığı tespit edilmiştir.

Düğ̈̈n Yemekleri: Bayram yemeklerinde olduğu gibi düğün yemeklerinde de mancar dolması mutlaka pişirilmektedir. Bunun yanı sıra, düğünlerde verilen yemekler arasında mercimek çorbası, mısır çorbası; tatlılardan da baklava ve nişasta helvasının olduğu tespit edilmiştir.

Cenaze Yemekleri: Araştırmada özellikle geçmişte cenazede verilen bir tane yemek ismine ulaşılmıştır. Cenazelerde nişasta helvası yapılarak, yufka ile servis edilirdi. Ölen kişi kaç yaşında 
ise o kadar yufka pişirilmekte, içerisine nişasta helvası konularak insanlara dağıtılmaktaydı. Günümüzde bu gelenek oldukça azalmıştır.

Standart Reçete 10. Aşure Çorbası

\begin{tabular}{|c|c|c|c|}
\hline \multicolumn{3}{|c|}{ Reçete: Aşure Çorbası } & Standart Reçete No:10 \\
\hline \multicolumn{4}{|c|}{$\begin{array}{l}\text { Miktar: } 5 \text { Porsiyon } \\
\text { Porsiyon Büyüklüğü: } 200 \text { gr. } \\
\text { Hazırlama Süresi: } 40 \mathrm{dk} . \\
\text { Pişirme Süresi: } 35 \mathrm{dk} . \\
\text { Toplam Maliyet: } 18,5 \mathrm{TL} \\
\text { Porsiyon Başına Maliyet: 3,7 TL }\end{array}$} \\
\hline Malzemeler & Miktar & Maliyet & Yapılışı \\
\hline Buğday & $200 \mathrm{gr}$ & $0,7 \mathrm{TL}$ & \multirow{10}{*}{$\begin{array}{l}\text { *Tüm baklagiller akşamdan suya konulur. } \\
\text { *Geniş bir tencereye buğday ve baklagiller ve } \\
\text { onların üstünü geçecek kadar su konulur, şeker } \\
\text { de eklenerek pişmeye bırakılır. } \\
\text { *Tüm malzemeler piştikten sonra (incir ve ceviz } \\
\text { hariç) kuru meyveler ve fındık ilave edilir. } \\
\text { Ocağın altı kapatılır. Suda ıslatarak yumuşatılan } \\
\text { incir ve son olarak da ceviz eklenerek servise } \\
\text { hazırlanır. }\end{array}$} \\
\hline Nohut & $100 \mathrm{gr}$ & $1,2 \mathrm{TL}$ & \\
\hline Kuru Fasulye & $100 \mathrm{gr}$ & $2 \mathrm{TL}$ & \\
\hline Şeker & $1080 \mathrm{gr}$ & $5,8 \mathrm{TL}$ & \\
\hline Findik & $60 \mathrm{gr}$ & $4 \mathrm{TL}$ & \\
\hline Ceviz & $60 \mathrm{gr}$ & $1,2 \mathrm{TL}$ & \\
\hline Kuru üzüm & $40 \mathrm{gr}$ & $0,4 \mathrm{TL}$ & \\
\hline Kuru incir & $40 \mathrm{gr}$ & $1,5 \mathrm{TL}$ & \\
\hline Kuru kayısı & $40 \mathrm{gr}$ & $0,7 \mathrm{TL}$ & \\
\hline Kuru dut & $40 \mathrm{gr}$ & $1 \mathrm{TL}$ & \\
\hline
\end{tabular}

\section{SONUÇ}

Yenice mutfak kültürünün vegan mutfak kapsamında incelenmesini amaçlayan bu çalışmada; Yenice yöresine özgü yemekler araştırılmış ve bu yemeklerin çoğunluğunun vegan yemekler olduğu tespit edilmiştir. Yerel kadınlar tarafından pişirilen, standart reçeteleri oluşturulan ve fotoğraflanan bu yemeklerin yapımında kullanılan malzemeler ve pişirme şekilleri, geçmişte ve günümüzdeki pişirme usulleri de dikkate alınarak kayıt altına alınmıştır.

Yenice'de geçmişten günümüze kadar en çok tüketilen besinlerin başında otlar ve sebzeler gelmektedir. Ayrıca, bakliyat olarak baklanın, tahıl olarak da mısır göcesinin mutfak kültüründe oldukça önemli bir yeri vardır. Gerek gündelik tüketimde gerekse ritüel yemeği olarak en çok kullanılan otlar Mancar (Karalahana) otu, ispıt otu, pazı, ısırgan otu, ebegümeci, madımak, tekesakalı, yemlik, tatala, toklamaç, labadadır. Dolayısı ile Yenice'nin tipik bir vegan mutfak özelliğine sahip olduğu görülmektedir.

Günümüze kadar devam eden ot pişirme yöntemlerinde herhangi bir değişikliğe rastlanmazken, kullanılan gıda maddelerinde bazı küçük değişiklikler olmuştur. Örneğin dolmalar eskiden mısır göcesi ile yapılırken günümüzde pirinç ve bulgur karışımı ile yapılmaktadır. 
Pırasa (göce ile pişirilir), Pazı (Çükündür-Kök pancarla pişirilir), Pazı kavurması, Acı mantar kızartması, Acı mantar kavurması ve acı mantar közlemesi yörenin önemli sebze yemekleridir. Yaz mevsiminde sebzeler ve meyveler taze olarak tüketilirken, kışın ise yazdan kurutularak tüketilmektedir. Özellikle taze fasulyenin yazın kurutulması ile yapılan fasulye yemeği kurutulmuş sebze yemeklerinin en önemlilerinden biridir. İç bakla, taze fasulye, patlıcan, biber, dolmalık biber gibi sebzeler ile elma, armut, ahlat, ayva, erik, mürdümeriği, vişne, kızılcık ve kuşburnu gibi meyveler kurutularak kışın da kullanılan malzemeler arasındadır. Ayrıca; Yenice mutfağında gerek kavurma ve yemeklerde gerekse hamur işlerinde mantarın ve bal kabağının önemli olduğu görülmektedir.

Pazı ve çükündür ile pişirilen "Çükündür yemeği", kuru fasulye ile yapılan mısır çorbası, sultani bakla tatlısı, lokma, baklava ve nişasta helvası özel günlerin özellikle de dini bayramların yemekleridir. Mancar (karalahana) dolmasının hem bayramlarda hem de dügüunlerde önemli bir ritüel yemeği olduğu saptanmıştır. Keza, cenazelerde nişasta helvasının geçmişten günümüze kadar halen devam eden bir ritüel tatlısı olduğu görülmektedir.

Yemek yapımında hayvansal gıda ürünlerine çok fazla rastlanmayan Yenice yemeklerinin vegan mutfağına oldukça uygun olduğu belirlenmiştir. Araştırmada belirlenen Yenice mutfak kültürüne özgü spesifik vegan yemekleri, özellikleri ve günümüze dek yaşanan değişiklikler aşağıda verilmektedir.

Yenice mutfağına özgü önemli vegan yiyecekler, bu yiyeceklerin günümüz ve geçmişteki özellikleri şunlardır;

Sebze yemekleri: Uzun Fasulye geçmişte de günümüzde olduğu gibi pişirilmekte olup fasulyeler kırılmadan uzun bir şekilde haşlanmakta, üzerine kızgın yağ ilave edilmektedir.

Sultani Salatası, eskiden yağ kullanmadan haşlanıp, yoğurt ile tüketilirdi. Günümüzde ise haşlanmış bakla, yağ ve soğan ile kavrularak pişirilir.

Eskiden balkabağının içine ceviz, bazen de şeker ilave edilmesi ile hazırlanan Balkabaklı Gözleme, günümüzde balkabağının soğanla kavrulması ve açılmış yufkaların içerisine bu harcın konularak saçta pişirilmesi ile hazırlanır.

Mantarlı Gözleme, eskiden olduğu gibi günümüzde de mantar ve soğanın baharat ile kavrulmasından sonra açılmış yufkanın içine konularak saçta pişirilmesi ile hazırlanır.

Ot yemekleri: Mancar Yemeği eskiden olduğu gibi günümüzde de karalahananın; göce, kara kabak, pırasa, pazı, havuç, ısırgan otu, ebegümeci gibi ot ve sebzelerden birkaçı ile pişirilmesiyle hazırlanır.

Mancar Dolması, haşlanmış karalahananın pirinç ve bulgur karışımından hazırlanan dolma içi ile sarılmasıyla yapılır. Eskiden yapımında iç malzemesi olarak yalnızca mısır göcesi kullanılırdı.

Ispıt Otu Kavurması, günümüzde de eskiden olduğu gibi haşlanmış ispıt otunun soğan ile kavrulmasıyla hazırlanır.

Otlu hamur işi: Otlu Mısır Ekmeği, eskiden mancar, ısırgan ve kabalak otunun mısır unu ile yoğrularak pişirilmesiyle hazırlanırdı. Günümüzde ise bu yiyecek pişirilmemektedir.

Tahıl çorbası: Göce Çorbası eskiden beri aynı yöntemle; mısır göcesi, bakla ve soğan ile pişirilmektedir.

Tahıl yemeği: Malay, eskiden beri mısır ununun kaynayan su içinde helva kıvamında pişirilmesi ile hazırlanir. 
Eskiden beri aynı yöntemle pişirilen Köfter Çorbası un, tuz ve su ile yoğrulan hamurun gelişigüzel kesilerek çorba şeklinde pişirilmesi ile hazırlanmaktadır.

Meyve tatlısı: Günümüzde de aynı şekilde hazırlanan Şaptak/Ovaz Tatlısının hazırlığı şu şekilde yapılır; ovaz meyvesi kurutularak taş değirmenlerde öğütülür sonrasında içine şeker ve sıcak su ilave edilerek hamur kıvamına getirilerek tüketilir.

Kurubaklagil tatlısı: Sultani (Kocabaklava) Tatlısı, haşlanmış baklanın şekerle karıştırılması ile hazırlanır. Sonrasında tepsiye dökülür ve soğuk olarak tüketilir. Eskiden şekerin yerine elma, ahlat, dut veya armut pekmezi kullanılırdı.

Tahıl tatlısı: Nişasta Helvası, buğday nişastasının sıvı yă̆, su ve şeker ile pişirilmesiyle hazırlanır. Geçmişte nişasta helvası yufkanın içine konularak dağıtılırdı.

Kurubaklagil ve kuru meyve tatlısı: Haşlanmış bazı kurubaklagillerin (kuru fasulye, nohut) buğday ve kuru meyvelerle (kayısı, incir, üzüm) pişirilmesiyle hazırlanan Aşure Çorbası kuruyemişlerle (ceviz, fındık) servis edilmektedir. Geçmişte hem şekerli hem de tuzlu olmak üzere iki şekilde yapılırdı. Tuzlu olanı kemik ile pişirilirdi.

Bölgenin yemek kültürünün kayıt altına alınmasını ve kültürel mirasın sürdürülebilirliğine katkı sağlamayı da amaçlayan bu araştırmanın en önemli sınırlılı̆̆ı, sadece ilçe merkezinde yapılan yemeklerin dikkate alınması, Yenice'nin köylerinin araştırmaya dahil edilememesidir. Bu bağlamda; bundan sonra yapılacak olan çalışmalarda Yenice'nin köylerinde ve kırsal alanlarda yapilan yemeklerin de incelenmesi yerinde olur.

\section{KAYNAKÇA}

Altaş, A. (2017). Vegetarianism and Veganism: Current Situation in Turkey in the Light of Examples in the World, Journal of Tourism and Gastronomy Studies, 5(4): 403-42.

Bode, W. (2000). European Gastronomy the Story of Man's Food and Eating Customs. London: Grub Street,

Canbulat, İ. (2014). Paflagonya Yemek Kültürü. https://gulevisafranbolu.wordpress.com/ Erişim Tarihi: 1.05.2019.

Creswell, W.J. (2017). Karma Yöntem Araştırmalarına Giriş, (Çeviren, Sözbilir, M.) Ankara: Pegem Akademi.

Çetin, Z., (2014). Vejetaryen ve Vegan Beslenmesi, Medikal Akademi. http://www.medikal akademi. com.tr/vejetaryen-ve-vegan-beslenmesi/ Erişim tarihi: 18.06.2019.

Dewan, M. (2017). My Vegetarian Experience: An Autoethnographic Approach, Asia-Pacific Journal of Innovation in Hospitality and Tourism, 6(1): 15-32.

Eren, S. (2014). Karabük Yemekleri. Zonguldak: Post ve Post Matbacılık.

Freedman, P. (2008). Yeni Bir Mutfak Tarihi, Yemek, (Editör). Freedman, P.: Damak Tadının Tarihi (s.s.1-30). İstanbul: Oğlak Güzel Kitaplar.

Ginsberg, C. (2017). The Market for Vegetarian Foods. http://kingsvegetarianfood.ca/wpcontent/uploads/2017/02/, Google Scholar, Erişim Tarihi.10.05.2019.

Hossein, S.M., Eftekhari M.H., Behnezhad, B.B. and Seyed, M.H. (2016). Vegetarian and Western Diets in Islam, Europe- Revue Litteraire Mensuelle, 532-535. https://www.researchgate.net/publication/305702527_Vegetarian_and_Western_Diets_in_Islam 
Erişim Tarihi: 10.11.2019

Ilgaz, A., Pınar, E., Özdemir, S.Y. (2016). Bir Tahakkük Biçimi Olarak Türcülük: Etin Cinsel Politikası Üzerine, ONTO Online Psikoloji Dergisi, Sayı 9, 44-48 http://www.ontodergisi.com/birtahakkuk-bicimi-olarak-turculuk-etin-cinsel-politikasi-uzerine/ Erişim Tarihi: 10.11.2019

Karabudak, E. (2012). Vejetaryan Beslenmesi. Ankara: Sağlık Bakanlığı Yayınları.

Karabük İl Kültür ve Turizm Müdürlügü (2019). Yiyecek-İçecek. https://karabuk.ktb.gov.tr/TR63744/yiyecek-icecek.html, Erişim Tarihi, 13.07.2019

Karabük Valiliği (2015). 81 İlde Kültür ve Şehir Karabük. İstanbul: Acar Basım.

Karakırık, H.ve Cebecik, K. (1996). Yenice. İstanbul: Aytur Basım-Yayım.

Kınıklığlu, M. (2016). Vegan Beslenme. İstanbul: Oğlak Yayınları.

Leitzmann, C. (2003). Nutrition Ecology: The Contribution of Vegetarian Diets. The American Journal of Clinical Nutrition, 78(3): 657-659.

Mariotti, F. and Dagnieli, P.C. (2017). Vegetarian Diets: Definition and Pitfall in Interpreting Literature on Health Effect of Vegetarianism, (Editor) François, M.: Vegetarian and Plant-Based Diets in Health and Disease Prevention) içinde (s.s.3-10) Academic Press.

McEvoy, C. T., Temple, N. and Woodside, J.V. (2012). Vegetarian Diets, Low-meat Diets and Health: A Review, Public Health Nutrition, 15(12): 2287-2294.

Özcan, T. ve Baysal, S. (2016). Vejetaryen Beslenme ve Sağlık Üzerine Etkileri, Uludağ Üniversitesi Ziraat Fakültesi Dergisi, 30(2): 101-116.

Özmen, C.Ö. (2017). Veganları Nasıl Bilirsiniz?: Türkiye'deki Veganlara Dair Anket Sonuçları,

Gaia Dergi. https://gaiadergi.com/veganlari-nasil-bilirsiniz-turkiyedeki-veganlara-dair-biranketin-sonuclari/ Erişim Tarihi: 01.09.2019

Petti, A., Palmieri, B., Vadalà, M. and Laurino, C. (2017). Vegetarianism and Veganism: not Only Benefits but Also Gaps. A Review. Progress in Nutrition, 19(3): 229-242.

Ruby, M.B. (2012). Vegetarianism. A Blossoming Field of Study, Appetite, 58, 141-150.

Ruby, M.B. and Heine, S.J. (2011). Meat, Morals, and Masculinity, Appetite, 56, 447-450.

Sezgin, A.C. ve Ayyıldız, S. (2019). Gastronomi Alanında Vejetaryen/Vegan Yaklaşımı; Giresun Yöre Mutfağı'nın Vejetaryen Mutfak Kapsamında İncelenmesi, Siyasi Sosyal ve Kültürel Yönleriyle Türkiye ve Rusya, 1(1): 505-53.

Standage, T. (2016). İnsanlığın Yeme Tarihi. İstanbul: Maya Kitap.

Sünnetçioğlu, S., Mercan, Ş.O., Yıldırım, H.M. ve Türkmen, S. (2017). Veganların Restoranlarda Karşılaştıkları Sorunlar Üzerine Bir Araştırma, Journal of Tourism and Gastronomy Studies, 5(2): 241252.

Şahin, N.N. (2016). Yiyecek ve İçecek Paradoksu (Editör) Doğdubay, M., Saatçi, G.: Yiyecek İçecek Sanatı ve Akımları içinde (s.s.61-106) Ankara: Detay Yayıncllık.

Şanlıer, N. ve Ertaş, Y. (2018). “Vejetaryen Mutfak”, (Editör) Nizamlıŏlu, F.: Gastronomide Güncel Konular içinde (s.s.133-164) Konya: Billur Yayınevi ve Basımevi.

Tez, Z. (2015). Lezzetin Tarihi, Geçmişten Bugüne Yiyecek İçecek ve Keyif Vericiler. İstanbul: Hayykitap. 
Tunçay, G.Y. (2016). Veganism in Terms of Bioethics from Different Viewpoints", Journal of Current Researches on Health Sector, 5(6): 51- 62.

Tunçay-Son, G.Y. ve Bulut, M. (2016). Yaşam Tarzı Olarak Vegan ve Vejetaryenlik, International Journal of Human Sciences, 13(1): 830-843.

Yegen C. ve Aydın, O. B., (2018). Postmodern Bir Kimlik Olarak Veganlık ve Bir Çevrimiçi Vegan Ağının Analizi, Galatasaray Üniversitesi İletişim Dergisi, 28: 91-114.

Yenice Kaymakamlığı (2020a). Kısaca Yenice. http://www.yenice.gov.tr/kisaca-yenice Erişim tarihi: 18.06.2020.

Yenice Kaymakamlığ1 (2020b). http://www.yenice.gov.tr/yoresel-yemek-cesitleri. Erişim tarihi: 18.06.2020.

Yıldırım, A. ve Şimşek, H. (2016). Sosyal Bilimlerde Nitel Araştırma Yöntemleri, Ankara: Seçkin Yayınları.

Wrenn, C. L. (2011). Resisting the Globalization of Speciesism: Vegan Abolitionism as a Site for Consumer-based Social Change, Journal for Critical Animal Studies, 9(3): 9-27.

\section{Görüşme Yapılan Kişiler}

Durkadın İncebacak

Hatice Kahveci

Azize Karadöngel

Dudu Misirlı

Hanife Misirlı

Meryem Misırlı

Hatice Sariavaz 